\title{
A Study Regarding the Attitudes that are Effective on the Price Perception of Consumers that Shop from the Retail Stores
}

\author{
Assist. Prof. Dr. Selda Ene \\ Marmara University, Vocational High School of Social Sciences, İstanbul \\ seldaene@marmara.edu.tr \\ Assist. Prof. Dr. Betül Özkaya \\ Marmara University, Faculty of Communication, Istanbul \\ betulozkaya@marmara.edu.tr
}

Doi:10.5901/mjss.2013.v4n11p451

\begin{abstract}
In this day and time, in which we experience an intense competition, being aware of the knowledge of the desires and demands of the consumers who shop from the retail setting and discovering the reasons behind these are important steps which will carry the businesses to success. According to various criteria, the consumer, by being effected by internal (sense, attitude, learning and instincts, etc.) and external (cultural factors, social class and lifestyle, etc.) factors, shape their decisions to purchase products and services. In this context, the businesses will be successful by prevailing in the competition, considering the recognition of the behaviour of the consumers that are in their target market and by improving the related marketing combination components (product, price, promotion and place). In order for the businesses to create efficient marketing programs and to reach their goal, they need to decide on the pricing decisions, in conjunction with other marketing combination elements (product, distribution and promotion) and considering the consumers in target market. In our study, in order to recognize the consumers in the target market and to reveal their price sensibilities, the examined issue is "the Attitudes That Are Effective on Consumer Price Perception". It is reflected that, recognizing the attitudes that are influential in consumers' price perceptions will enable the better understanding of the consumers in the target market and the establishment of a better service. In this study which relies on this purpose, surveys has been conducted to understand the "Attitudes That Are Effective on Consumer Price Perception" and the resulting "Purchasing Behaviours" of the consumers in Turkey. For the survey, consumers who are over 18 years old and shop from the retail stores are interviewed face to face and convenience sampling method has been used. Factor analysis and regression has been applied to the results that are obtained. It is reflected that the study results will be beneficial for the national or international businesses.
\end{abstract}

Keywords: Retail Shopping, Price in Retail Stores, Consumer's Perception of Price, Consumers' Shopping Behaviours and Attitudes

\section{Introduction}

In the dynamic market environment, where the competition is intense, retail businesses will act according to the modern marketing concepts and the consumer satisfaction will be the focal point of their activities (Okumuş, 2004: 28). In order to survive and succeed in the intense competitive environment, retail businesses will have to determine how consumers decide on their purchasing decisions by being effected through internal (perception, attitude, learning and instincts, etc.) and external (cultural factors, social class and lifestyle, etc.) factors. When the businesses develop marketing strategy that will have a positive effect on the consumer behaviours of the target group, they will also position their products and services within price-quality relationship. When applying pricing strategies, prices will be determined according to the values that are presented to the consumers and thus, the price perception of the consumers will be shaped accordingly.

Price perceptions occupy an important place in the consumers' product choices and purchasing behaviours. When talking about consumers' price perception, rational factors (quality and value, etc.) and psychological factors (prestige, etc.) are evaluated in conjunction with each other and these factors are essential of the businesses (Kurtuluş ve Okumuş, 2006: 4). For this reason, it has started to become a widely analysed subject in academic studies.

The goal of this study is to identify the consumers that are in the target group and to reveal consumers' price sensibilities and the consumers of "Attitudes That Are Effective on their Price Perception" and "Purchasing Behaviours" in Turkey, which they expose during shopping, is analysed by conducting surveys. For the survey application, 554 
consumers, who are over 18 years old and shop from the retail stores in Turkey, are interviewed face to face and convenience sampling method has been used. Factor analysis and regression has been applied to the results that are obtained.

\section{Price Perceptions of Consumers}

When determining the price of the products they produce and market, retail businesses consider many factors, from the cost of the product to its image, from advertisement costs to operation costs and they determine a pricing according to these factors. Rather than the price deciding factors that consumers have, the important factor that concerns the consumers is the value they gets in exchange for the price (Doyle, 2003: 462). Assessments regarding the price-value relationship effect the purchase decision of customers (http://www.isletmeportali.com/konular/satis/musterilerin-fiyatalgilamasi-3.html, 2012).

Retail businesses can also adopt different pricing purposes. Generally, it is possible to compile these purposes under three categories: "Struggle to survive, financial purposes and marketing-oriented purposes". The businesses, who strive to exist in the intense competitive environment, keep their prices as low as possible and wish to increase their sales. Those businesses, who do not find themselves in a struggle to survive, may follow a pricing policy that can help them to reach various financial goals. These businesses choose the price that will enable maximum profit, investment return and cash flow by reviewing demand structures under various price alternatives and costs. On the other hand, some businesses may choose the path that increases the market share and sales volume and protects the position and the status quo and enables achieving marketing purposes (Altunışık vd., 2004: 194-195).

The businesses must be prepared for three topics (3p) that are closely related to each other and will enable them to act according to marketing purposes, in regards to price and services. These are; 1. Perception, 2. Placebo, 3. Positioning. Thus, the businesses can position their products and services within price-quality-value relation, on the consumers' minds by creating a placebo effect: (Gilkey, 2010; http://www.productiveflourishing.com/the-3ps-of-pricingperception-part-1/, 2012)

1. Perception: Perception is to obtain information of an event or an object, with the help of senses. Among the factors that affect perception are physical features of the stimulant (i.e. a colourful newspaper ad or attractiveness of a package), stimulant's relationship with the environment and the attributes of the environment in which the individual is situated (Mucuk, 2009: 78). The consumer behaviour can also occur according to the messages that are portrayed, along with the perception of these (Özer, 2009: 1). Perception, which is formed either individually or under the influence of environmental factors, affects the consumer behaviour in many respects (Eray, 2007). Under these, perception of advertisement, perception of product image and corporate image and perception of price can be listed. Price perception, which is the process of consumers commenting on the price and attributing value to the products or services, has started to be a topic that the marketing experts work and investigate on. Therefore, the existence of an absolute relationship between the price and value is referred on the conducted studies.

2. Placebo: The businesses, with the marketing strategies, have intended to create a placebo effect on the minds of the consumers and they have succeeded. The principle of Placebo is "to believe". The consumers are mentally affected by the external factors (i.e advertisements), being oblivious of their effects. Besides, our life experiences and personal beliefs are affected, in favour of products and services, with us being totally unaware. After the occurrence of this contagion, rather than the quality of the product and the product that is presented, there will be an expectation and belief in our minds, regarding that product (http://www.productiveflourishing.com/the-3ps-of-pricing-perception-part-2/, 2012). Thus, different and superior features of the product and services will be positioned in the minds of consumers, compared to the competitors.

3. Positioning: Positioning strategy should be discussed in terms of external positioning (superior features compared to products and services of the competition) and internal positioning (ability to be produced as a more innovative, creative and remarkable product) by the businesses and price should be determined according to these conditions (http://www.productiveflourishing.com/the-3ps-of-pricing-perception-part-3/, 2012). The purpose here is to be perceived as an innovative and a creative product - along with having a product that can only compete with price - (Çelik et.al., 2012) and to be positioned by creating a placebo effect with a successful value-quality perception.

Retail businesses consider these matters below when applying pricing policies that aim to reach marketing goals 
(Doyle, 2003: 462);

$\checkmark$ In order to establish a brand loyalty, pricing should be attributed to the values that are presented to the consumers, not to the production costs.

$\checkmark$ Since consumers ascribe different values to products and services, the price should be harmonized with the customers; so that the differences created by the value can be used as an opportunity.

$\checkmark$ Pricing should be integrated with the positioning and the goals of the business. Moreover, pricing decisions should estimate the long term strategies and the reactions of the competitors.

Among the main pricing methods that will enable the retail businesses to improve customer loyalty with their pricing policies, "pricing affiliated with quantity", "pricing affiliated with time and customer loyalty duration", "multiple product pricing", multi-individual pricing (group price)", "long term purchase and guarantee contracts" can be listed (Gülçubuk, 2008: 19). With these applicable pricing methods, they will present the customer with convenient values and opportunities, create positive perceptions on consumers' minds and form loyal customers.

Price perception holds a significant importance in consumers' product preferences and purchase behaviours (Dickson and Sawyer, 1990: 42). Economists and marketing researchers occasionally conducted various studies in order to estimate and to understand the effect of price on purchase behaviour. When talking about the consumers' price perception, rational and psychological factors are evaluated together. While quality and value come into prominence in rational factors, prestige awareness shine out in psychological factors. Better the psychological process regarding the consumers' price perception is defined; more improved the probability of making correct decisions with regards to consumers' price perception will be (Kurtuluş and Okumuş, 2006: 4).

Consumers' price perceptions occur in a process. According to this, consumer obtains the price information both visually and auditory, he/she interprets this information and achieves a various, meaningful results from this information (Okumuş, 2003: 50). Along with internal evaluations, the consumers decide their purchase decisions by being effected by external stimuli and form their brand decisions. While making purchase decisions, they can obtain various attitudes through purchase experience and learning or they develop new attitudes. When a consumer decides on a particular brand, he/she follows this process (Geçti and Zengin, 2012: 38-39). In a study conducted in 2008 by Meng and Nasco and in 1993 by Lichtenstein et. al., the researchers have found out that internal factors constitute a much large impact compared to the external factors (environments like advertisement, etc., price presentations) in consumers' price perception (Meng and Nasco, 2008).

In the studies where the factors, that are influential in purchase behaviours of the consumers that shop from the retail stores, are analysed, it is seen that "price perceptions" hold the first place among other factors. In the study which Nielsen company conducted in 56 countries in 2012, "the 16 different factors which influence the consumers who shop from retail businesses" have been analysed. According to the results of the study, the first five factors are "product price, health conditions, transportation costs, package and debt decisions". First placed "price of food products" is seen to be most direct influence on purchase decisions (http://www.nielsen.com/us/en/newswire/2012/global-survey-says-risingprices-greatest-factor-in-grocery-purchase-decisions.html, 2012).

The price perception, which is the interpretation of price and attribution of value by the consumers and the effect of price on product evaluation have also been analysed on conducted studies and initially, price has been addressed as one aspect. And in some studies has addressed that price could have more than one role in deciding the purchase. In the study conducted by Zeithaml in 1988, price perception aspects are seen as relation of "perceived price, perceived quality and perceived value" (Zeithaml, 1988: 2).

In the studies where the attitudes that are effective in consumers' price perception are analysed, price perception aspects are grouped as follows: "Price- Quality Schema, Prestige Sensitivity, Price Consciousness, Value Consciousness, Price Mavenism, Sale Proneness, Coupon Proneness) (Lichtenstein, Ridgway and Netemeyer, 1993). In the studies conducted later on, Domestic and Foreign product consciousness has been added to this aspect (Okumuş, 2004; Kurtuluş and Okumuş, 2006; Geçti and Zengin, 2012).

In the study conducted by Duman and Yağcı, the impact of five main factors which are determined with regards to customer behaviour in Turkish supermarkets, on continuous shopping intentions are tested. These factors are determined as "price perception, discount perception, product quality perception, service quality perception and value perception." According to the results of this study, the shopping intentions of supermarket customers are substantially affected by "discount perception, product quality perception and value perception" (Duman and Yağcl, 2006).

In the study conducted by Sternquist et. al. in 2004, price perception aspects are studied thoroughly and price perception aspects are classified as negative aspects (Price Awareness, Value Consciousness, Price Mavenism, Sale Proneness) and positive aspects (Price-Quality Schema, Prestige Sensibility). Different price perception aspects have 
been implemented on consumers in China and Korea and when the difference is analysed it has been seen that Chinese consumers perceive the price only in terms of negative aspects (Sternquist et. al., 2004:83). In their study conducted in 2012. Mendoza and Baines accentuated on the existence and importance of relation between price perception and willingness to pay and actual purchase behaviour. In addition, it has been suggested that after the establishment of purchase behaviour and even after the establishment of new price information, price perception is found to be a process that is dynamically regenerated (Mendoza and Baines, 2012: 287).

\section{A Study of Attitudes that are Effective on Price Perceptions of Consumers who Shop from Retail Stores}

Price perceptions hold an important place in product and service preferences, purchase behaviours of consumers that shop from the retail stores. For this reason, the price perceptions of consumers matter for the businesses (Kurtuluş ve Okumuş, 2006: 4). Therefore, it has started to become a subject that is analysed in academic studies.

In this study where we intend to identify the consumers situated in target group and to reveal their price sensibilities, "Attitudes That Are Effective on Consumer Price Perception and consumers' "Purchase Behaviours" are analysed.

\subsection{Purpose, Scope of the Study}

Presenting the attitudes that are influential on price perceptions of the consumers that shop from retail stores will enable a better understanding of the consumers in target group and a better service development. With this in mind, this study contains analyses that is comprised of a survey study with regards to "Attitudes that are Effective on Price Perceptions of Consumers who Shop from Retail Stores" and "Purchase Behaviours" that they present during shopping.

In the research model of the study, the relationship between consumers' "Attitudes that are Effective on Price Perceptions" and "Purchase Behaviours" that they present during shopping is analysed. In order to analyse consumers' "Attitudes that are Effective on Price Perceptions", the studies of Lichtenstein, et. al (1993), Okumuş (2004), Kurtuluş and Okumuş (2006), Meng and Nasco (2008), Geçti and Zengin (2012) were used (Bearden and Netemeyer, 1999: 273; Lichtenstein, Ridgway and Netemeyer, 1993; Okumuş, 2004; Kurtuluş and Okumuş, 2006; Meng and Nasco, 2008; Geçti and Zengin, 2012).

In order to study the "Purchase Behaviours" that the consumers present during shopping, "Planned shopping behaviour, unplanned shopping behaviour, purchase frequency (every day, once a week, once a month" can be discussed. The studies conducted for this purpose, - study of Ergin and Akbay, conducted in 2011, regarding "unplanned shopping behaviour" in food and garment retail shops; study of Altunışık and Çallı, conducted in 2004, regarding "unplanned shopping behaviours"; study by Turan, conducted in 2011, regarding "planned, shopping behaviours" and study by Akat et. al, conducted in 2006, regarding "planned, unplanned shopping behaviour and shopping frequency" have been taken as models and set as a model (Ergin and Akbay, 2011: 275; Altunışık and Çallı, 2004: 231; Turan, 2011: 128; Akat et.al., 2006).

The survey work of the study has been performed by conducting face to face interviews with 554 individuals that are over 18 years of age and shoppers of retail stores in Turkey and convenience sampling method has been used. In the survey where "Attitudes that are Effective on Price Perceptions" and "Purchase Behaviours" that the consumers exhibit during shopping, Likert Scale has been used (1. Strongly Disagree, 2. Disagree, 3. Neutral, 4. Agree, 5. Strongly Agree). The relationship between the variables that are surfaced as a result of factor analysis of "Behaviours that are Effective on Consumer Price Perceptions" and "Purchase Behaviours" that are exhibited in retail stores are analysed with regression analysis as to determine whether they exist or not.

\subsection{Methodology of the Study}

The constrains, model and bulk sample selection of the are explained below.

\subsubsection{Constraints of the Study}

In this study, consumers' "Attitudes that are Effective on Price Perceptions" and "Purchase Behaviours" have been analysed through survey study. The constraint for the main mass of the study is to be comprised of individuals that are over 18 years of age and are able to decide, by their own rights, to shop from retail stores in Turkey and the application 
of survey study to the shoppers in the hours in which the shops are open. Survey study has been performed by interviewing face to face with 554 individuals and convenience sampling method has been used.

\subsubsection{Model of the Study}

The study model, which is created in order to explain consumers' "Attitudes that are Effective on Price Perceptions" and "Purchase Behaviours" that they exhibit during shopping, is as follows (Figure 3.1)

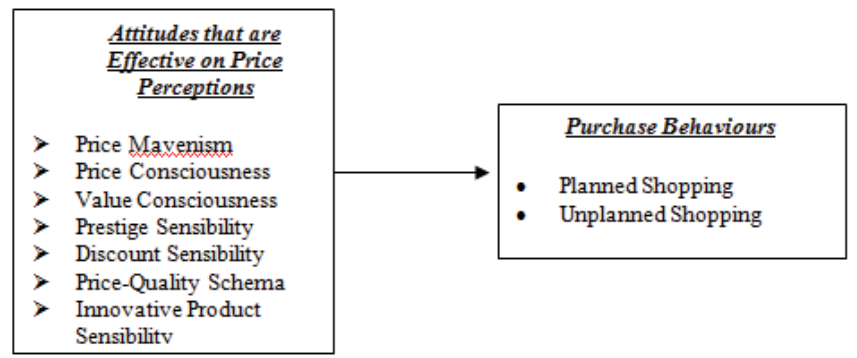

Figure 3.1. A Study Model on the Relationship Between Consumers' "Behaviours that are Effective on Price Perceptions" and "Purchase Behaviours"

The hypotheses of the study are included below. By discussing these hypotheses, sub-hypothesis are created and analyses are made.

$\mathbf{H}_{1}$ : There is a suggestive relation between consumers' "Attitudes that are Effective on Price Perceptions" and "Planned Purchase Behaviours".

$\mathrm{H}_{2}$ : There is a suggestive relation between consumers' "Attitudes that are Effective on Price Perceptions" and "Unplanned Purchase Behaviours.

The scale for consumers' "Attitudes that are Effective on Price Perceptions" and "Purchase Behaviours" that they exhibit during shopping is created by referring to the sources included in the table below (Table 3.1).

Table 3.1. The Scale Table of "Attitudes that are Influential in Price Perceptions" and "Purchase Behaviours"

\begin{tabular}{|l|l|}
\hline \multicolumn{1}{|c|}{ Variable } & \multicolumn{1}{c|}{ Source } \\
\hline \multicolumn{1}{|c|}{ Attitudes that are Influential on Price Perceptions } \\
\hline$\quad$ Price Mavenism & (Lichtenstein, Ridgway and Netemeyer, 1993) \\
$>\quad$ Price Consciousness & (Okumuş, 2004) \\
$>\quad$ Value Consciousness & (Kurtuluş and Okumuş, 2006) \\
$>$ Prestige Sensitivity & \\
$>$ Sale Proneness & (Meng and Nasco, 2008) \\
$>\quad$ Price-Quality Schema & (Geçti and Zengin, 2012) \\
$>\quad$ Innovative Product Sensitivity & (Ergin and Akbay, 2011: 275) \\
\hline Purchase Behaviours & (Altunışık and Çall, 2004: 231) \\
\hline Planned Shopping & (Turan, 2011: 128) (Akat and et.al, 2006) \\
\hline
\end{tabular}

\subsubsection{Determination of Study Bulk Sample}

The survey work of the study has been conducted with face to face interviews with 554 individuals who are over 18 years of age that shop from retail stores in Turkey and convenience sampling method has been used.

\subsection{Findings of the Study}

The analysis of the study has been examined by separating into two sections: definitional and deductional. 


\subsubsection{Definitional Analysis Findings}

The individuals who have participated in the survey are chosen from those who shop from retail stores, make their own minds in terms of shopping and are over 18 years old. The demographic features, sex, education, income, age and marital status of 554 individuals have been analysed. The consumers consist of 554 individuals, of which $54.9 \%$ of is women and $44.9 \%$ of is men. The education status of these consumers is as follows: "19.5\% elementary education, $36.6 \%$ high school education, $26.7 \%$ associate degree, $13.5 \%$ bachelor's degree, 3.5\% post graduate." Distribution of income of the consumers is: $41.5 \%$ between, " $500-1.000$ TL, 29.2\% between $2.001-3.000,6.5 \%$ between 3.001 4.000 and above. Consumers' age ranges are: $37 \%$ between $18-25 ; 24.2 \%$ between $26-35 ; 22 \%$ between $36-45 ; 13.2 \%$ between $46-55$ and $3.4 \%$ for 56 and above. Consumers' marital statuses are $42.4 \%$ married, $43.7 \%$ single, $7.6 \%$ widower and $6.1 \%$ divorced.

The scale of consumers' 'Attitudes that are Influential in Price Perceptions' consists of 30 questions. 30 questions are subjected to question factor analysis and this has emerged seven factor groups; these are: "Price Mavenism: PM, Price Consciousness: PC, Value Consciousness: VC, Prestige Sensitivity: PRS, Sale Proneness: SP, Price- Quality Schema: PQS, Innovative Product Sensitivity: IPS" (Table 3.2). As a result of credibility analysis which has been conducted in 0.05 relevance level of 'Attitudes that are Influential in Price Perceptions', which is comprised of 30 variables, Cronbach's Alpha Value is found to be 0.876 . Moreover, a credibility analysis has been performed to each of the seven factor groups in the study and Cronbach's Alpha Value is examined (Table 3.2).

Alpha value carries values between 0 and 1 and it desired for the admissible value to be at least 0.7 (Altunışık et. al., 2005: 116). Therefore, it can be stated that the credibility of the scale, along with the credibility of each factor group in itself, is significantly high.

In the factor analysis, which has been performed to the 'Attitudes that are Influential in Price Perceptions' which consists of 30 questions; when Kaiser-Meyer-Olkin (KMO) sample efficiency test is applied; relevance value is to be found 0.000 and $\mathrm{KMO}$ value is to be found 0.782 . The test of factor analysis of practicability to any data set is measured with 'Kaiser-Meyer-Olkin (KMO) sample efficiency test. KMO value can be admissible in values between 0.5-1.0 (Altunışık et. al., 2005: 217). Therefore KMO value of 0,782 is believed to be sufficient enough for factor analysis.

Also, it has been examined that the seven factors which has been obtained in the study has attested the $63.33 \%$ of total variance. The factor groups which are obtained as a result of factor analysis, the credibility of factor groups and factor loads of the components that constitute factor groups are given in Table 3.2.

Table 3.2. Factor Analysis Results of "Attitudes that are Effective on Price Perceptions"

\begin{tabular}{|c|c|c|c|c|}
\hline $\begin{array}{l}\text { Factor } \\
\text { Group }\end{array}$ & $\begin{array}{l}\text { Name of the } \\
\text { Factor Group }\end{array}$ & $\begin{array}{c}\text { Credibility of } \\
\text { Factor Group } \\
\text { (Cronbach's Alfa } \\
\text { Coefficient ) }\end{array}$ & Attitudes that are Influential on Price Perceptions & $\begin{array}{l}\text { Factor } \\
\text { Loads }\end{array}$ \\
\hline Factor 1 & Price Mavenism & 0,863 & $\begin{array}{l}\text { * People consult me regarding information about different types } \\
\text { of products. } \\
\text { * Regarding knowledge of product prices, I am seen as an } \\
\text { expert. } \\
\text { * I am better than most of the people who give information to } \\
\text { those that seek most appropriate price.. } \\
\text { * l like to help people about price information of many product } \\
\text { types. } \\
\text { * My friends see me as a reliable price information source. }\end{array}$ & $\begin{array}{l}0,621 \\
0.823 \\
0.827 \\
0.793 \\
0.773\end{array}$ \\
\hline Factor 2 & $\begin{array}{c}\text { Price } \\
\text { Consciousness }\end{array}$ & 0,858 & $\begin{array}{l}\text { * I walk about all stores for low prices, but I look for a certain } \\
\text { quality criteria before purchase. } \\
\star \text { I make an effort to search for low prices. } \\
\star \text { In order to obtain a low price advantage, I search for different } \\
\text { stores. } \\
\text { * In order to save money by finding a low-priced product, it } \\
\text { generally pays off to spend time and effort. } \\
\text { * The time spent on finding a low price product is a time worth } \\
\text { spending. }\end{array}$ & $\begin{array}{l}0,579 \\
0.795 \\
0.792 \\
0.7784 \\
0.701\end{array}$ \\
\hline
\end{tabular}




\begin{tabular}{|c|c|c|c|c|}
\hline Factor 3 & $\begin{array}{c}\text { Value } \\
\text { Consciousness }\end{array}$ & 0.843 & $\begin{array}{l}\text { * I am interested in low prices, along with quality. } \\
\star \text { In order to make sure that I get bang for my buck, I compare } \\
\text { the prices of different brands. } \\
* \text { I make sure that I get maximum quality products for the money } \\
\text { I spend. } \\
\text { * I'd like to be sure that my purchase justifies the value of my } \\
\text { money. }\end{array}$ & $\begin{array}{l}0.722 \\
0.758 \\
0.798 \\
0.823\end{array}$ \\
\hline Factor 4 & $\begin{array}{l}\text { Prestige } \\
\text { Sensitivity }\end{array}$ & 0.875 & $\begin{array}{l}\text { * Purchasing a high-priced brand makes me feel better. } \\
\text { * } \text { Purchasing the most expensive brand of a product makes me } \\
\text { feel more prestigious (classy). } \\
\star \\
* \text { I like the prestigious feeling of buying high-priced product. } \\
\star \text { When an individual purchase a high-priced product, this } \\
\text { enables them to convey a positive and prestigious message. }\end{array}$ & $\begin{array}{l}0.603 \\
0.873 \\
0.911 \\
0.768\end{array}$ \\
\hline Factor 5 & Sale Proneness & 0.803 & $\begin{array}{l}\text { * Purchasing products and services that are at discount makes } \\
\text { me feel better. } \\
\text { * Discount of products and services can be a reason for me to } \\
\text { make a purchase. } \\
\text { * It is a high probability for me to buy products and services that } \\
\text { are at discount. } \\
\text { * It makes me happy to collect discount coupons and money } \\
\text { points and make purchases by saving money. } \\
\text { *I have my favourite brands, but most of the time I choose the } \\
\text { discounted brands. }\end{array}$ & $\begin{array}{l}0.661 \\
0.792 \\
0.850 \\
0.618 \\
0.607\end{array}$ \\
\hline Factor 6 & $\begin{array}{l}\text { Price- Quality } \\
\text { Schema }\end{array}$ & 0.804 & $\begin{array}{l}\text { * Generally it is mentioned that higher price means higher } \\
\text { quality. } \\
\text { * The saying 'what you pay is what you get' is generally correct. } \\
\text { × The price of a product is a good indication of its quality. } \\
\text { * We always have to pay a little bit more for the best. }\end{array}$ & $\begin{array}{l}0.603 \\
0.793 \\
0.807 \\
0.774\end{array}$ \\
\hline Factor 7 & $\begin{array}{l}\text { Innovative } \\
\text { Product } \\
\text { Sensitivity }\end{array}$ & 0.737 & $\begin{array}{l}\text { * When I purchase a new brand, I feel like I've accomplish } \\
\text { something good. } \\
\star \text { I have my favourite brands, but most of the time I choose the } \\
\text { ones that are newly released and presented. } \\
\text { * It suits me fine to purchase newly released products. }\end{array}$ & $\begin{array}{l}0.841 \\
0.814 \\
0.599\end{array}$ \\
\hline
\end{tabular}

\subsubsection{Deductional Analysis Findings}

The deductional analysis of the study has been examined as follows:

Abbreviations for Dependant Variables "Purchase Behaviours" are below:

$>$ Planned Shopping: PS

$>$ Unplanned Shopping: UPS

Abbreviations for Independent Variables Attitudes That Are Effective on Consumer Price Perception are below:

$>$ Price Mavenism: PM

Price Consciousness: PC

$>$ Value Consciousness: VC

$>$ Prestige Sensitivity: PRS

$>$ Sale Proneness: SP

$>$ Price- Quality Schema: PQS

$>$ Innovative Product Sensitivity: IPS

Attitudes That Are Effective on Consumer Price Perception is comprised of 30 questions and as a result of the factor analysis, seven factor groups have emerged. Seven factor groups form the independent variables of regression analysis.

Each of the Purchase Behaviours are thought to be a dependant variable and for every purchase behaviour that has been thought to be a dependant variable, a hypothesis is created, showed as an equation and its relation with independent variables (Attitudes that are Effective on Price Perceptions) is analysed with regression analysis.

In the regression analysis of the study; application has been made by integrating all variables with stepwise method for every hypothesis test. Due to various iterations, the model has emerged. In the testing of hypotheses in these studies, as a result of the iterations of stepwise method, final model has been presented. 
The first hypothesis of the study and regression analysis result regarding this hypothesis are given below:

First Hypothesis;

$\mathrm{H1}$ : There is a suggestive relation between consumers' Attitudes that are Effective on Price Perceptions" and "Planned Purchase Behaviour".

The regression formula, which explains the relation appearing above hypothesis, is expressed as the equation of; $\mathrm{PS}=2.931+0.114 \mathrm{PM}+0.181 \mathrm{PC}+0.174 \mathrm{VC}$.

Table 3.3. Regression Analysis Model Summary of the Relation Between Consumers' "Attitudes that are Effective on Price Perceptions" and "Planned Purchase Behaviours"

\begin{tabular}{|c|c|c|c|c|}
\hline Model & $\mathrm{R}$ & $\mathrm{R}^{2}$ & Corrected $\mathrm{R}^{2}$ & Standard Error of Estimate \\
\hline 3 & 0.221 & $\mathbf{0 . 0 4 9}$ & $\mathbf{0 . 0 4 4}$ & 1.219 \\
\hline
\end{tabular}

Table 3.4. Regression Analysis ANOVA Table of the Relation Between Consumers' "Attitudes that are Effective on Price Perceptions" and "Planned Purchase Behaviours"

\begin{tabular}{|c|c|c|c|c|c|c|}
\hline Model & & $\begin{array}{c}\text { Sum of } \\
\text { Square }\end{array}$ & sd & $\begin{array}{c}\text { Average } \\
\text { Square }\end{array}$ & $F$ & $p$ - value \\
\hline 3 & Regression & 41.896 & 3 & 13.965 & 9.390 & 0.000 \\
\hline & Balance & 813.484 & 547 & 1.487 & & \\
\hline & Total & 855.379 & 550 & & & \\
\hline
\end{tabular}

The model which has been tested with regression analysis is statistically relevant $(F=9.390$ and $p=0.000)$. Because , relevance level of $F$ value is smaller than $(p<0.05), 0.05$.

Seven factors, which have been obtained as a result of the factor analysis, constitute the independent variables of regression analysis. Our dependant variable is 'Planned Shopping' (PS). As a result of regression analysis, it is seen that the factors which have a relevant effect on planned shopping are independent variables that are: "Price Mavenism: PM, Price Consciousness: PC, Value Consciousness: VC". Independent variable explains the $0.044 \%\left(R^{2}\right.$ value) of the change in dependant variable.

Result of the regression analysis, "Beta value (B) projection of the relation between 'Attitudes that are Effective on Price Perceptions' and "Planned Purchase Behaviours", standard error values, $t$ values, $p$ values and VIF values are shown in Table 3.5.

Table 3.5. "Beta, Standard Error, t, p, VIF Value Results as consequence of Regression Analysis of Relation Between 'Attitudes that are Effective on Price Perceptions' and 'Planned Purchase Behaviours'

\begin{tabular}{|l|c|c|c|c|}
\hline Independent Variables & & PM & PC & VC \\
\hline Beta Value Values & 2.931 & 0.114 & 0.181 & 0.174 \\
\hline Std. Error Value & 0.052 & 0.052 & 0.052 & 0.052 \\
\hline T Value & 56.418 & 2.198 & 3.476 & 3.356 \\
\hline p Value & 0.000 & 0.028 & 0.001 & 0.001 \\
\hline VIF value & & 1.000 & 1.000 & -1.000 \\
\hline
\end{tabular}

$\mathrm{H} 1$ hypothesis has been tested with the regression analysis of there is a suggestive relation between consumers' Attitudes that are Effective on Price Perceptions" and "Planned Purchase Behaviour". As a result of the regression analysis, it has been examined that three ("Price Mavenism: PM, Price Consciousnesse: PC, Value Consciousness : $\left(V C^{\prime \prime}\right)$ of the seven factor groups, which constitute the independent variables, have suggestive, statistical effect on planned purchase behaviour and $\mathrm{H} 1$ hypothesis could not be validated.

The second hypothesis of the study and regression analysis results regarding this hypothesis can be found below. Second Hypothesis;

H2: There is a suggestive relation between consumers' Attitudes that are Effective on Price Perceptions" and "Unplanned Purchase Behaviour.

The regression formula, which explains the relation appearing above hypothesis, is expressed as the equation of; 
Table 3.6. Regression Analysis Model Summary of the Relation Between Consumers' "Attitudes that are Effective on Price Perceptions" and "Unplanned Purchase Behaviours

\begin{tabular}{|c|c|c|c|c|}
\hline Model & $\mathrm{R}$ & $\mathrm{R}^{2}$ & Corrected $\mathrm{R}^{2}$ & Standard Error of Estimate \\
\hline 2 & 0.189 & $\mathbf{0 . 0 3 6}$ & $\mathbf{0 . 0 3 2}$ & 1.218 \\
\hline
\end{tabular}

Table 3.7. Regression Analysis ANOVA Table of the Relation Between Consumers' "Attitudes that are Effective on Price Perceptions" and "Unplanned Purchase Behaviours

\begin{tabular}{|c|c|c|c|c|c|c|}
\hline Model & & $\begin{array}{c}\text { Sum of } \\
\text { Square }\end{array}$ & sd & $\begin{array}{c}\text { Average } \\
\text { Square }\end{array}$ & $F$ & $p$ - value \\
\hline 2 & Regression & 29.978 & 2 & 14.989 & 10.107 & 0.000 \\
\hline & Balance & 812.704 & 548 & 1.483 & & \\
\hline & Total & 842.682 & 550 & & & \\
\hline
\end{tabular}

The model which has been tested with regression analysis is statistically relevant $(F=10.107$ and $p=0.000)$. Because , relevance level of $F$ value is smaller than $(p<0.05), 0.05$.

Seven factors, which have been obtained as a result of the factor analysis, constitute the independent variables of regression analysis. Our dependant variable is 'Unplanned Shopping (UPS). As a result of regression analysis, it is seen that the factors which have a relevant effect on planned shopping are independent variables that are: "Prestige Sensitivity: PRS and Sale Proneness: SP" Independent variable explain the $0.032 \%$ ( $\mathrm{R}^{2}$ value) of the change in dependant variable.

Result of the regression analysis, "Beta value (B) projection of the relation between 'Attitudes that are Effective on Price Perceptions' and "Unplanned Purchase Behaviours", standard error values, $t$ values, $p$ values and VIF values are shown in Table 3.8.

Table 3.8. Beta, Standard Error, t, p, VIF Value Results as Consequence of Regression Analysis of Relation Between 'Attitudes that are Effective on Price Perceptions' and 'Unplanned Purchase Behaviours'

\begin{tabular}{|l|c|c|c|}
\hline Independent Variables & & PRS & SP \\
\hline Beta Value Values & 2.893 & 0.187 & -0.140 \\
\hline Std. Error Value & 0.052 & 0.052 & 0.052 \\
\hline T Value & 55.762 & 3.604 & -2.688 \\
\hline p Value & 0.000 & 0.000 & 0.007 \\
\hline VIF value & & 1,000 & 1.000 \\
\hline
\end{tabular}

H2 hypothesis has been tested with the regression analysis of There is a suggestive relation between consumers' Attitudes that are Effective on Price Perceptions" and "Unplanned Purchase Behaviour". As a result of the regression analysis, it has been examined that only two ("Prestige Sensitivity: PRS, and PC, Sale Proneness: VC") of the seven factor groups, which constitute the independent variables, have suggestive, statistical effect on unplanned purchase behaviour and $\mathrm{H} 2$ hypothesis could not be validated.

Deciding whether independent variables, which affect the "Purchase Behaviours", possess multiple connections or not, was accomplished by examining VIF values (ie. Interaction of variable with each other) on the regression analysis table In the statistical analyses, VIF values between 1-10 show that there is no correlation issue. In this study, VIF values of independent variables were examined, it was observed that all of them obtained values of 1.000 and therefore, due to the fact that they obtained values between 1 and 10 , it has been deduced that the variables did not affect each other.

As the result of conducted analysis;

" $\mathrm{H} 1$ hypothesis has been tested with the regression analysis of there is a suggestive relation between consumers' "Attitudes that are Effective on Price Perceptions" and "Planned Purchase Behaviour". As a result of the regression analysis, it has been examined that three ("Price Mavenism: PM, Price Consciousnesse: PC, Value Consciousness : (VC") of the seven factor groups, which constitute the independent variables, have suggestive, statistical effect on 
planned purchase behaviour and there is no suggestive effect for the other independent variables. $\mathrm{H} 1$ hypothesis could not be validated. H1 hypothesis was partly validated for only three variables. With a 0.181 unit increase, 'Price Consciousness: PC' is in 1st place; with a 0.174 unit incease 'Value Consciousness: VC' resides in 2nd place and with 0.114 unit increase 'Price Mavenism: PM' holds 3rd place and prompts 'planned purchase behaviour' in adjuvant direction.

$\mathrm{H} 2$ hypothesis has been tested with the regression analysis of There is a suggestive relation between consumers' Attitudes that are Effective on Price Perceptions" and "Unplanned Purchase Behaviour". As a result of the regression analysis, it has been examined that only two ("Prestige Sensitivity: PRS, and PC, Sale Proneness: VC") of the seven factor groups, which constitute the independent variables, have suggestive, statistical effect on unplanned purchase behaviour and $\mathrm{H} 2$ hypothesis could not be validated. With a 0.187 unit increase, 'Prestige Sensitivity: PRS' prompts 'unplanned purchase behaviour2 in adjuvant direction. With a 0.140 unit decrease, 'Sale Proneness: SP', prompts the 'unplanned purchase behaviour' in detractive direction and affects it negatively.

\section{Conclusion and Assessment}

It is strategically very important to determine the truest strategies and decisions in pricing of the products and services that the retail businesses put on market (Özden and Oktay, 2099: 159). The businesses which will determine the marketing strategies for the purpose of meeting the desires and needs of the target customers by acting in accordance with the modern marketing insights, will be successful when compared to others in the intense competition environment. Retail businesses will evaluate the customers who have different price perceptions, as different market segments and will determine their target groups. Determination of customers' attitudes regarding the price perceptions and examination of these customer perceptions with regard to effected purchase behaviours will enable the businesses to know their target groups in a better way and thus, present a better service.

Prepared for this purpose, this study has studied the "Attitudes that are Effective on Price Perceptions" and "Purchase Behaviours" of consumers' in Turkey, with a survey study. For the survey study, 554 consumers who are over 18 years of age and shop from the retail stores in Turkey, were interviewed face to face. Factor analysis and regression analysis were applied to the data that were obtained from the survey.

In this study, where the goal is to identify the consumers who shop from the retail stores in Turkey, the scale of Consumers' 'Attitudes that are Effective on Price Perceptions' was subjected to factor analysis and seven factor groups have emerged. These seven factor groups are; "Price Mavenism: PM, Price Consciousness: PC, Value Consciousness: VC, Prestige Sensitivity: PRS, Sale Proneness: SP, Price - Quality Schema: PQS, Innovative Product Sensitivity: IPS. In the factor analysis result of the study, unlike the studies conducted before, "Innovative Product Sensitivity: IPS" factor group has emerged in this study. These emerged factor groups have been determined as independent variable and it has been attempted to understand how it affects the purchase behaviour (planned purchase behaviour and unplanned purchase behaviour) which is a dependant variable.

In the regression analysis result of the study; first hypothesis, the independent variables that affect "planned purchase behaviour" which is the dependent variable, are analysed. Only three of the seven factors ("Price Mavenism: PM, Price Consciousness: PC, Value Consciousness: VC") that constitute independent variables are seen to have a statistical, suggestive effect on planned purchase behaviour and it is examined that none of the other independent variables are seen to have any other effect. It has been examined that three factor groups have presented a positive and increased effect on planned purchase behaviour.

In the regression analysis result of the study; second hypothesis, the independent variables that affect "unplanned purchase behaviour" which is the dependent variable, are analysed and effects of two factor groups are observed. Only two of the seven factors ("Prestige Sensitivity: PRS and Sale Proneness: SP") that constitute independent variables are seen to have a statistical, suggestive effect on unplanned purchase behaviour. While "Prestige Sensitivity: PRS" is found to increase unplanned purchase behaviour positively, "Sale Proneness: SP" is found to be affected negatively, in a detractive direction.

As the result of the study, the factors that are beyond the consumers' purchase behaviours are explained. The reasons behind the planned and unplanned purchase behaviours of the consumers are explained in terms of "consumers' attitudes regarding price perceptions". It has been set forth which of the consumer attitudes towards price perceptions have an impact on planned purchase behaviours and which have an impact on unplanned purchase behaviours and whether they increase the purchase behaviours or not.

With the study results; it is aimed to determine the attitudes that are effective on consumers' price perceptions in 
Turkey, to determine how these attitudes affect the purchase behaviour and to get a better understanding of the consumers in the target group and to develop better services. Thus, there will be beneficial results for the retail store managers who wish to develop marketing strategies to positively affect consumers in the target groups. This will enable retail businesses to acquire competitive advantages, compared to their competitors and to improve their successes. The results of the study are believed to be beneficial for national or international retail businesses.

In the studies hereupon, attitudes are effective in price perceptions of the customers that are in different sectors, can be measured. Other than the retail sector, "Attitudes that are Effective on Price Perceptions" and "Purchase Behaviours", "Brand Loyalties" during shopping, can be measured, with regards to wholesaler or manufacturing business customers. The study can be adapted to online environment and a scale can be developed with regards to customers' attitude towards price perception.

\section{References}

Akat, Ömer, Çağatan Taşkın, Aysun Özdemir, (2006), "Uluslararası Alısveris Merkezi Tüketicilerinin Satın Alma Davranışı: Bursa llinde Bir Uygulama", Anadolu Üniversitesi, Sosyal Bilimler Dergisi, 6(2): 3-30.

Altunışık, Remzi, Şuayıp Özdemir, Ömer Torlak, (2004), Modern Pazarlama, Değişim Yayınları, 3. Baskı, İstanbul.

Altunışık, Remzi, Levent Çallı, (2004), "Plansız Alışveriş (Impulse Buying) ve Hazcı Tüketim Davranışları Üzerine Bir Araştırma: Satın Alma Karar Sürecinde Bilgi Kulllanımı", 3. Ulusal Bilgi, Ekonomi ve Yönetim Kongresi, Eskişehir: Osmangazi Üniversitesi, 25- 26 Kasım,231-240, (http://iibf.ogu.edu.tr/kongre/bildiriler/05-04.pdf), (22.03.2007)

Altunışık, Remzi, Recai Coşkun, Serkan Bayraktaroğlu, Engin Yıldııım, (Ekim 2005), Sosyal Bilimlerde Araştırma Yöntemleri - SPSS Uygulamalı, Adapazarı: Sakarya Kitabevi, Geliştirilmiş 4. Baskı.

Bearden, William O., Richard G. Netemeyer, (1999), Handbook of Marketing Scales - Second Edition, Multi-Item Measures for Marketing and Consumer Behavior Research, Sage Publications, Inc., California, USA.

Çelik, Neslihan, Selda Ene, Başak Değerli, (2012), "Dinamik Girişimcilikte Yenilikçilik Anlayışı: Online Ortamda Kullanıcıların Yeniliklere Bakış Açıları ile İlgili uygulama", 4. Uluslararası Girişimcilik Kongresi, Celal Bayar Üniversitesi ve Kırgızistan-Türkiye Manas Üniversitesi işbirliğinde, Manisa, 2-4 Mayıs.

Dickson, Peter R., Alan G. Sawyer, (July 1990), "The Price Knowledge and Search of Supermarket Shoppers", Journal of Marketing, 54 (3): $42-53$.

Doyle, Peter, (2003), Değer Temelli Pazarlama: Şirketinizi Büyütmek ve Hissedar Değeri Yaratmak İçin Pazarlama Stratejileri, Çeviri: Gülfidan Barış, MediaCat Kitapları, Kapital Medya Hiz. A.Ş., İstanbul.

Duman, Teoman, Mehmet Yağcı, (2006), "Süpermarket Müşterilerinin Devamlı Alş̧veriş Niyetlerini Etkileyen Faktörler: Bir Model Denemesi", METU Studies in Development, 33(1), (http://www2.feas.metu.edu.tr/metusd/ojs/index.php/metusd/rt/ printerFriendly/98/0), (02.06.2013).

Eray, Fatma, (2007), "Hazır Giyim Sanayinde Marka-Reklam ve Tüketici Ilişkileri", (http://www.bakterim.net/tekstil/45627-hazir-giyimsanayinde-marka-reklam-ve-tuketici-liskileri.html), (10.06.2013).

Ergin, Elif Akagün, Handan Özdemir Akbay, (2011), "Giyim ve Gıda Ürünleri Kategorilerinde Tüketicilerin Plansız Satın Alma Davranışları Üzerine Bir Araşıırma", Afyon Kocatepe Üniversitesi, İ̈BF Dergisi, 13(2): 275-292.

Fatih Geçti ve Hayrettin Zengin, (2012), " Fiyat Algılamasının Boyutları Arasındaki Illişkilerin İncelenmesi: Akıllı Telefon Tüketicilerine Yönelik Bir Araşıırma", Sakarya İktisat Dergisi, 1(4):37-74, (www.sakaryaiktisat.sakarya.edu.tr/dergimakale/sayı4/37-74.pdf), (15.06.2013).

Gilkey, Charlie, (April 2010), "The 3Ps of Pricing: Perception", (http://www.productiveflourishing.com/the-3ps-of-pricing-perception-part1/), (06.06.2013).

Gülçubuk, Ali, (2008), "Müşteri Bağlıı̆ı Yaratmada Fiyat Politikasının Önemi ve Uygulanan Fiyatlandırma Yöntemlerinin Değerlendirilmesi", Celal Bayar Üniversitesi,Yönetim ve Ekonomi Dergisi, 15(1):15-26.

Kemal Kurtuluş ve Abdullah Okumuş, (Şubat 2006), "Fiyat Algılamasının Boyutları Arasındaki ilişkilerin Yapısal Eşitlik Modeli İle İncelenmesi", İstanbul Üniversitesi İşletme İktisadı Enstitüsü Yönetim Dergisi, 17(53): 3-17.

Lichtenstein, Donald, Nancy M. Ridgeway, and Richard G. Netemeyer, (May 1993) "Price. Perceptions and Consumer Shopping Behavior: A Field Study," Journal of Marketing Research, 30(2): 234-245.

Meng, Juan Gloria, Suzanne A. Nasco, (Summer 2008), "The Direct Effects of Price Perception Constructs and Internal Reference Price on Consumers's Price Perception", European Journal of Management, 8(2), International Academy of Business and Economics ISSN: 1555-4015.

Mendoza, José, Paul Baines, (2012), "Towards a Consumer Price Perception Formation Framework: A Systematic Review", (http://anzmac.org/conference/2012/papers/173ANZMACFINAL.pdf), (05.06.2013).

Mucuk, İsmet, (2009), Pazarlama Illkeleri ve Yönetimi İçin Örnek Olaylar, Türkmen Kitabevi, Geliştirilmiş 17. Basım, İstanbul.

Nielsen Company, (2012), "Rising Prices Greatest Factor in Grocery Purchase Decisions", 2013. (http://www.nielsen.com/us/en Inewswire/2012/global-survey-says-rising-prices-greatest-factor-in-grocery-purchase-decisions.html), (01.06.2013).

Okumuş, Abdullah, (Haziran 2004), "Perakendecilik Sektöründe Tüketicilerin Fiyat Algılamalarına Göre Bölümlendirilmesi", Yönetim Dergisi, 15(48): 27-38. 
Özden, Kenan, Kutay Oktay, (2009), "Kırgızistan'da GSM Operatörleri Müşterilerinin Fiyat Algılamalarına Yönelik Bir Araştırma”, Sosyo Ekonomi Dergisi, Temmuz-Aralık, 2: 159-175.

Özer, Nur, (2009), Algılama ve Pazarlama Uygulamaları", Paradoks Ekonomi, Sosyoloji ve Politika Dergisi, 5(1):1-12, e-dergi, (http://www.paradoks.org), (04.06.2013).

Sternquist, Brenda, SangEun Byun, Byoungho Jin, (2004), "The Dimensionality of Price Perceptions: A Cross-Cultural Comparison of Asian Consumers", The International Review of Retail, Distribution and Consumer Research, 14(1): 83-100.

Turan, Aykut Hamit, (2011), "İnternet Alışverişi Tüketici Davranışını Belirleyen Etmenler: Planlı Davranış Teorisi (TPB) ile Ampirik Bir Test”, Doğuş Üniversitesi Dergisi, 12(1): 128-143.

Zeithaml, Valarie A., (July 1988), "Consumer Perception of Price, Quality and Value: A Means-End Model and Synthesis of Evidence", Journal of Marketing, 52(3): 2-22, (http://journal.dogus.edu.tr/index.php/duj/issue/view/1), (15.06.2013) 